ROCZNIKI NAUK SPOŁECZNYCH

Tom 13(49), numer 3 - 2021

DOI: https://doi.org/10.18290/rns21493.3

JOEL B. BABALOLA

ADESOJI A. ONI

\title{
TRANSFORMING INDIGENOUS KNOWLEDGE AND INNOVATION SYSTEMS FOR AFRICAN INTELLECTUAL DECOLONIZATION AND RENAISSANCE
}

\section{INTRODUCTION}

In the last three decades, serious efforts have been made to solve development of most third world countries, especially in Africa, but with little success, The development problems of concerns are many and include economic, social, physical, agricultural, technological and human resources development to mention a few. It is therefore an ideal time to discuss why past efforts have not been able to provide lasting solutions that meet the needs and aspirations of these countries.

The erroneous belief that indigenous systems are simple and static is no longer tenable. Rather, many societies with what looks like simple technologies have very complex and sophisticated knowledge about evolution and rationale if only we care to look beyond the surface. Several changes which we see are predicated upon conscious efforts by people in an attempt to come to grip with their problems and seek solutions through local experimentation, innovation and evolution. This has made the application of knowledge (measured in term of entrepreneurship and innovations, research and development, as well as software and product design) to become one of the spring boards of economic growth. Until quite recently however, few in the developed world cared very

Joel B. Babalola - Professor of Educational Management at the Faculty of Education, Department of Educational Management, University of Ibadan, Ibadan, Nigeria; address for correspondence: e-mail: joelbabalola2000@gmail.com; ORCID: https://orcid.org/0000-0002-7468-9352.

AdESOJI A. ONI-Associate Professor of Sociology of Education at the Faculty of Education, Department of Educational Foundations, University of Lagos, Akoka-Yaba, Lagos, Nigeria; address for correspondence: e-mail: aoluoni@yahoo.com; ORCID: https://orcid.org/0000-0001-6774-2672. 
much about the loss of indigenous knowledge. The prevailing attitude has been that the western science with its powerful analytical tool has nothing to learn from indigenous knowledge.

Today, however, the developed world concern for the state of environment has somewhat increased their interest in indigenous knowledge and some scientists are beginning to recognize that the world is losing an enormous amount of beginning to recognize that the world is losing an enormous amount of basic materials as indigenous knowledge disappears.

In spite of the fact that developing countries can capitalize on the on-going knowledge revolution, studies such as World Bank (2007) have shown that many of them lack the capacity to tap and apply global knowledge to their needs. Yet, it is well documented that countries in African are endowed to build their human capital, institutions, infrastructure like power, transportation and communication technologies, and enterprises (Babalola, Emunemu, 2003, 2006; Babalola et al., 2008a, 2008b, 2008c; Babalola, 2012, 2013, 2014, 2015).

This shows how knowledge is now highly valued as transformational change agent and we are said to be living in the age of knowledge characterized by a knowledge economy, This means that knowledge itself and the uses of knowledge are nothing new for mankind which understands itself through languages which are themselves symbolic systems for cultivating and transferring knowledge. In fact, it could be said that the capacity to gather, analyse and use knowledge has been a crucial element throughout the history of mankind (McNeill, McNeill, 2006). What makes the idea of the knowledge society exceptional is the quantity of knowledge (and information) produced daily and the use of ICT in data intensive processes.

However, it can be argued that the modernization processes within the knowledge society are processes of extension rather than social transformation that define a fundamentally new era of human existence.

Hence the objectives of this paper are to promote and advance the recognition and advancement of indigenous knowledge in Africa for African intellectual decolonization and Renaissance and use it in policy and decision making process, especially with respect to knowledge dissemination in the classroom. Specifically, this paper will:

1) identify major challenges facing African countries in leveraging on intellectual advances; and 2) suggest ways to make knowledge and innovation to work better for African intellectual decolonization and revitalization. 


\section{THE CONCEPTUAL CLARIFICATION}

Wallace (2007), defines knowledge as the sum of what is known; a body of truths, principles and information; specific information require to develop the skills and attitudes for effective accomplishment of jobs, duties, and tasks. Similarly, Dewey (1938) defines Knowledge is defined as the gain of facts, information, and truth. In philosophy any principle, theory or concept which fits into this definition is considered as knowledge. Now wonder teachers and educators used the term 'concept of knowledge' refers to the information that teacher teach and students are expected to learn in given subject or content area. Knowledge is related to the facts, concepts, theories, and principles that are taught. In other words, 'Knowledge' derives from 'to know,' 'education' is the ability to apply that knowledge to real life situations, to behave as a civilized person to organize family, society etc. it refers to organized learning with these objectives. One can acquire general education or go in for specializations and become a professional-doctor, lawyer, engineer, teacher etc. So knowledge can be seen as an intellectual content processed by an organization and any piece of information that a worker knows, from customer names to how to fix a piece of machinery; that can be codified in a variety of formats, such as power point slides, word documents, audio and video files.

Indigenous knowledge can be described as a local knowledge, which is unique to a given culture or society. It is the information base for any society (Richard, Slikkerveer, Philips, 1989). It is also a consistent and coherent set of cognition and technologies that has slowly evolved through the trial and error of generations of farmers who had to live by the results (Warren, Cashman, 1989, p. 103). Kotschi, Waters-Bayer, Adelhelon, and Hoeste (1989) further described indigenous knowledge as low eternal input system making use of locally available energy and material and practical environmental knowledge. Such techniques and strategies can be regarded as the result of deliberate efforts to improve and/or protect the environment. Contrary to what the term may seem to imply or connotes, "traditional" or local knowledge is not necessarily simple, neither does it occur in a vacuum. It is ever changing, and very often borrows selectively from outsiders, that sustain the productive resources based (Warren et al., 1989, p. 102). In addition indigenous knowledge provides alternative methods of solving problems in cases where outsides or exogenous solutions to local problems do not fit the local systems. Also, due to knowledge diversity, indigenous knowledge can become a vital resource for development, 
while it represents information on a range of production systems that can provide important clues for innovation.

With the foregoing we can see that indigenous knowledge is important because it optimally utilizes available resources, explore and exploits existing diversities, takes into account the instability of the environment, and provides livelihood whilst appreciating the This is to argue that a knowledge system is the systematic organization of innovation and knowledge asset embodied in education, training, science and technology for effective and efficient creation, absorption adaption and propagation of the revealed body of truths for evolutionary, revolutionary, transformational and routine purposes in the society. In other words, an innovation system can be built up by firms, research centers, universities, think tanks, consultants, and other organizations, especially, knowledge organizations, yet the intellectual and the university are at the core.

According to Mazrui (2005, p. 56) an intellectual is a person who has the capacity to be curious and fascinated by ideas and has acquired the skill to handle, articulate ideas effectively. Intellectualism is an engagement in the realm of ideas, rational discourse and independent enquiry. Therefore, a university has three crucial relationships which include; culturally close to society; and intellectually linked to wider scholarly and scientific values in the world of learning (p. 62). In another development, Chambers Dictionary (1998), states that a university is an institution of higher learning comprising teachers, students, and graduates that are endowed with power to grant degrees. Though the university is a fertile ground for intellectual development and intellectualism, intellectuals are not limited only to the university since it is possible to have pure philosophers like Wole Soyinka based in universities and research organizations, while, philosophers like Julius Nyerere of Tanzania and Jomo Kenyatta of Kenya in politics and knowledge workers in work places such as the case of Fredrick Taylor.

Intellectual renaissance on the other hand, is the reinvigoration and retooling of non-organic and immature intellectuals who are based in various interacting parts of the knowledge systems to imbibe and be immersed in the current global spirit of intellectualism, thereby catching the intellectual fire required to make things happen in a knowledge economy (Babalola, 2012). On the hand, Transformation is defined by Babalola (2015) simply as "change" and indigenous means home-grown or local as different from foreign. Thus, transforming the indigenous knowledge system connotes changing the existing knowledge and innovation system so that the evolving model will enjoy sustainable public finance and yet be politically distant. More so, that such local 
innovation system will be intellectually linked with scholarly and scientific values of the global world of learning without compromising its role to be culturally close to the immediate society. This change can take the form of revolution, reforms and routine alterations in the intellectual features.

\section{AFRICAN HISTORY THROUGH DEVELOPMENT}

One of the first significant global developments was the transition from the nomadic way of life of hunting and gathering to agricultural cultivation in settled communities. Africa played a leading role during this Neolithic Revolution, as Ethiopian highlands, the Sahel and West Africa independently developed agriculture and domesticated coffee, sorghum and Kola nut respectively. Other crops domesticated in Africa during this golden period include millet, rice, yam and palm oil (Sousa, Raizada, 2020). Typically, in the early stages of development, economies had most of their outputs and labour force in agriculture. However, Soubbotina (2004) in his book Beyond Economic Growth: An Introduction to Sustainable Development explained how per capita income increased, agriculture lost its dominance, giving way first to a rise in the industrial sector, then to a rise in the manufacturing, construction, and commercial sectors. In spite of the fact that Africa was one of the brains behind agricultural development during the Neolithic Revolution, the industrial revolution missed Africa for so many reasons including colonization and its consequent underdeveloped indigenous thinking (Nwokeabia, 2001). Although, when and how migrations occurred is highly debated, it is widely agreed upon that original routes of human migration began with emigrations from Africa into the Mideast, Asia, and Europe, and only much later from Asia to the Americas. Nonetheless, it is clear that Africa encountered and successfully overcame barriers that hindered free flow at the period. If Africa achieved these feats in the past when there was no schooling, why the passivity in Africa today in the midst of so many intellectuals? In 38 years, the World Bank supported Nigeria to the tune of about $38 \%$ of the country's total education budget in each of the eight fiscal years. Lending for university education projects accounted for as much as $43.75 \%$ of Nigeria's total education budgets in 1990 and 17.74\% in 2003 (Babalola, 2011). Unfortunately, Nigeria has been Africa's leading borrower for higher education since 1986 (World Bank, 1994, p. 81). 
Below are highlights of index report of low level of access to education at strategic levels:

1. Basic education is a prerequisite for knowledge absorption.

2. Average years of schooling by working adults that was 10 years in high-income economies was 5.5 years in low-income countries found in Africa (Soubbotina, 2004).

3. Tertiary \& postgraduate education is a catalyst to knowledge creation.

4. Africa had the lowest gross enrolment ratio [4\%] compared with other world regions among others.

In the words of IBRD/World Bank (2000, p. 32-33), several gaps were observed between industrial countries and Africa. For the purpose of this paper the following are highlighted:

1. Industrial countries have been by far the greatest contributors to, and beneficiaries of, this knowledge revolution.

2. To the extent that if this trend continues, the income gap between industrial and developing countries will widen further.

3. Higher education institutions, as the prime creators and conveyors of knowledge, must be at the forefront of efforts to narrow the development gap between industrial and developing countries.

\section{EFFECTS OF ACCUMULATION AND APPLICATION OF KNOWLEDGE ON ECONOMIC PERFORMANCE}

There has been a significant positive correlation between knowledge economy index (KEI) and economic development with a value $R^{2}=0.8735$. Thus, countries with higher KEI value tend to have higher levels of economic development, and vice versa. Moreover, econometric tests reveal a statistically significant causal relationship between the level of knowledge accumulation, as measured by the KEI, and future economic growth. A one-unit improvement in the KEI leads to an increase of 0.49 percentage points in economic growth, after accounting for initial conditions. Thus, larger stocks of knowledge do indeed cause higher levels of economic growth and development. These results confirm that knowledge and its applications play a major role in growth processes. 


\section{INTELLECTUALISM AND INTELLECTUAL DEVELOPMENT}

Colonial education and socialization treated the educated elite as a class of highly privileged individuals who stood over and above their communities, grooming them to become second class heirs of "civilization" meaning Western culture, religion and their knowledge systems. Their communities according to Migo (2004) were dismissed as "uneducated" their religions were condemned as "heathen" and their cultures/education systems dubbed "primitive". The Western educated became chronic travelers along what V. S. Naipul once referred to as the step road to "whiteness." Fortunately, among them there emerged rebels and dissidents who revolted against this grooming for membership into a privileged colonial class of blacks. However, the majority toed the line. In their zeal to reach the top of the mountain, those who collaborated internalized a culture of self-hatred and pathetic contempt for their people. The treacherous class of a collaborating elite has been analyzed and written about by a lot of critical thinkers. Frantz Fanon has called them the "these walking lies" and dismissed them as creatures without content. With these "disaster" in view, Walter Rodney challenges scholars who intend to make theory with practice and combine scholarship with activism, with the aim of bringing about revolutionary change. Many others according to Migo (2004) that have written on this theme including; Amilcar Cabral, Angela Davis, Nwalimu Julius Nyerere, Bell Hooks, Ngugi wa Thiong'o etc.

Under the neo-colonialism, the dilemma of African intellectuals was heightened, while divisions among various groupings/classification was intensified. With the incarceration of the 1960s to the 1990s, a significant class of intellectuals were successfully coerced or inducted into propagating what Wole Soyinka once called the "cult of court poet." This class of intellectuals has persisted up to this stage of accelerated democratic change and plays a very treacherous role in validating the continuing capture and sometimes attempted erasure of the state by dictatorial leaders across Africa.

In this vein, all over Africa, many opportunistic intellectuals have not just supported repression at home but also supplied active service for foreign interest. Many of them constitute a club of bureaucrats responsible for shaping anti-collective developmental policies for neo-colonial African government, the World Bank, the IMF and other dominating global institutions that marginalize poor Africans as well as other impoverished people in the World.

Intellectuals have always been engaged in social, economic and political life of the society. History is full of examples of the close relationship between 
intellectualism and socio-economic transformation. The Biblical Judea experienced national revival to transform from dry bones to a great army as a result of revelation received by Prophet Ezekiel one of the great minds during monotheism in 221 BC (Ezekiel 37:1-15).

The Greek science in the $8^{\text {th }}$ Century BC focused on the universe with Pythagoras and Euclid as earliest popular critical minds. Theophrastus, disciple of Aristotle, found botanical science. The screw for raising water was invented by Archimedes in applied sciences. In the $13^{\text {th }}$ Century, the medieval papacy thought through Scholasticism, an intellectual system, which employed Aristotle's logic in all fields of inquiry. The result was a revolution in the methods and content of learning which produced a coherent system of philosophy and theology. Scholastic controversy was the relationship between revelation and reason. Aristotle challenged primacy of theology by asserting that rationality was the basis of knowledge.

\section{PRODUCT OF THE GRADUAL DEINTELLECTUALIZATION OF AFRICAN ACADEMIA}

By the 1990s, most African countries started to witness a phenomenon of non-organic intellectuals characterized by apathy to their social responsibilities and moral obligation to speak out and challenge misrepresentations of truth in science and the society. This was mainly as a result of the general political distrust of Africa's intellectuals and the increased reliance on foreigners, philosopher-kings syndrome and the drastic resource curtailment following the Structural Adjustment Programme in the continent. The 2000s can best be described as a period of intellectual inaudibility and struggle characterized by complete passivity and marginality of intellectuals in the political and social life and struggle for survival through strike actions and double commitment in search of pasture. By year 2000, the value attached to the academy and the academic had reduced significantly compared with what it used to be at independence in most countries of Africa. These trends have led to an unnecessary characterization and typology of African intellectuals into 'old' and 'new' generations as can be seen in Table 1. 
Table 1. Generational Classification of Intellectuals in Africa

\begin{tabular}{|l|l|l|l|l|}
\hline \multirow{2}{*}{ Profile } & \multicolumn{4}{|c|}{ Generations of Intellectuals } \\
\cline { 2 - 5 } & \multicolumn{1}{|c|}{ First (1960s) } & \multicolumn{1}{|c|}{ Second (1970s) } & \multicolumn{1}{|c|}{ Third (1980s) } & \multicolumn{1}{|c|}{ Fourth (1990s) } \\
\hline $\begin{array}{l}\text { Exposure and } \\
\text { prestige (attached } \\
\text { to services) }\end{array}$ & $\begin{array}{l}\text { Foreign-grown } \\
\text { Non-African } \\
\text { scholars highly } \\
\text { valued }\end{array}$ & $\begin{array}{l}\text { Foreign-grown } \\
\text { African scholars } \\
\text { with highly valued } \\
\text { contributions } \\
\text { to society }\end{array}$ & $\begin{array}{l}\text { Home-grown } \\
\text { African scholars } \\
\text { whose services } \\
\text { are lowly valued }\end{array}$ & $\begin{array}{l}\text { Home-grown } \\
\text { African scholars } \\
\text { in diaspora } \\
\text { whose services } \\
\text { are relatively } \\
\text { valued }\end{array}$ \\
\hline $\begin{array}{l}\text { Expertise and } \\
\text { position (inside } \\
\text { or outside voice } \\
\text { as it affects } \\
\text { personality) }\end{array}$ & $\begin{array}{l}\text { Critical and } \\
\text { analytical using } \\
\text { outsider voice } \\
\text { to represent the } \\
\text { truth with decisive } \\
\text { objectivity }\end{array}$ & $\begin{array}{l}\text { Critical and } \\
\text { analytical using } \\
\text { insider voice } \\
\text { to represent the } \\
\text { truth with decisive } \\
\text { objectivity }\end{array}$ & $\begin{array}{l}\text { Less critical, less } \\
\text { analytical and } \\
\text { less confident } \\
\text { to represent the } \\
\text { truth with } \\
\text { decisive } \\
\text { objectivity }\end{array}$ & $\begin{array}{l}\text { Critical and } \\
\text { analytical despite } \\
\text { relatively low } \\
\text { insider voice } \\
\text { to represent } \\
\text { to the truth }\end{array}$ \\
\hline $\begin{array}{l}\text { Engagement and } \\
\text { prowess } \\
\text { (to challenge } \\
\text { misrepresentation) }\end{array}$ & $\begin{array}{l}\text { Highly engaging } \\
\text { science, society } \\
\text { and students using } \\
\text { foreign ideas but } \\
\text { no urge } \\
\text { to challenge } \\
\text { foreign and local } \\
\text { misrepresentations }\end{array}$ & $\begin{array}{l}\text { Vibrantly engaging } \\
\text { the society and } \\
\text { students with local } \\
\text { and foreign ideas } \\
\text { with strong urge } \\
\text { to challenge } \\
\text { foreign and local } \\
\text { misrepresentations }\end{array}$ & $\begin{array}{l}\text { Lacks the } \\
\text { academic } \\
\text { inclination } \\
\text { to engage the } \\
\text { society and } \\
\text { no urge } \\
\text { to challenge } \\
\text { foreign and even } \\
\text { local } \\
\text { misrepresentations }\end{array}$ & $\begin{array}{l}\text { Vibrantly } \\
\text { engaging the } \\
\text { society and } \\
\text { students but with } \\
\text { low indigenous } \\
\text { voice to } \\
\text { challenge local } \\
\text { misrepresentations }\end{array}$ \\
\hline
\end{tabular}

Source: Babalola (2014).

From the foregoing, one can see that there is a progressive deintellectualization in Africa owing to changing intellectual environment.

\section{INTELLECTUALISM AND INTELLECTUAL DEVELOPMENT DURING RENAISSANCE, REFORMATION AND ENLIGHTENMENT}

Renaissance begins with Humanism or classical revival, the growth of printing, politics and humanism, rise and spread of Flemish music, Italian and English Renaissance, the high Renaissance in Florence and Rome, the high Renaissance in north Italy, German and Netherlands. Renaissance, rejection 
of local tradition and development of sculpture and architecture; French Renaissance culture from conflict; all were intellectual agendas (Babalola, 2015). The $17^{\text {th }}$ Century saw the emergence of the enlightenment, a belief among European philosophers and writers that the truth about the nature of man and his world could be discovered by the use of reason. The Industrial Revolution started in Europe following the rediscovery of knowledge during the Renaissance and the resulting Scientific Revolution. The Greek had developed an investigative approach that led to important discoveries in astronomy, physics, and mathematics Romans later added important engineering techniques. On the basis of this accumulation of knowledge, Europe gave birth to the renaissance explosion in science, art and other areas of knowledge development. Europe encouraged publicizing ingenuity and rewarding inventors under the patent system of the statute of monopolies of 1623. Consequently, inventors such as James Watt were allowed to monopolize the production to motivate them to produce and also protect them from competition. As a result of the cold war, United States universities, especially elite institutions such as Harvard and Yale, receive hundreds of millions of dollars for research relating to military and scientific projects. Enormous grants begin to influence university budgets and shift priorities away from teaching and toward research.

As noted by Mazrui (2005, p. 56), the origins of modern intellectualism and the origins of Pan-Africanism are intertwined. We can imagine intellectualism without Pan-Africanism, but we cannot envisage pan-Africanism without the intellectualization of the African conditions. It is not a historical accident that the founding fathers of the Pan-Africanist movement like W. E. B. Dubois, Kwame Nkrumah, George Padmore, and Leopold Senghor were disproportionately intellectuals.

\section{PROCESS OF DEINTELLECTUALIZATION OF AFRICAN ACADEMIA}

There is a general belief that there is a correspondence between the intellectual system and the society. The environment affects the intellectual system and the intellectual system is expected to impact its context. It is generally agreed that the society should provide minimal enabling environment within which intellectual system can work effectively for the societal development. It can be argued that lack of enabling intellectual environment has been responsible 
for the bulk of deintellectualization of the intellectual being experienced in most African countries.

Bamiro (2012) rightly identified the problem of "gradual deintellectualization of the academia and the intellectualization of indolence and mediocrity in some of our institutions" in Nigeria. According to him, the problem can be traced to the following four factors (1) low quality of staff and student, (2) poor resource in-flow, (3) unfavourable governance and (4) devastating effects of the series of strikes which resulted in total lockouts. While these four factors can adequately explain the weaknesses of the academic life in Nigeria, and in fact, in Africa as a whole, they are not sufficient to proffer lasting solution to the problem. For instance, there is no doubt that strike actions had some devastating effects on the academic life in Nigeria. Incessant strike action can promote among other anti-intellectual attitudes, double commitment whereby half of the mind is for intellectual activities and the other half for survival strategies in times of strike, moon lightening in which half of the intellectual time is spent on non-intellectual matters, public mind in which intellectuals think that they work to earn public salary rather than public recognition and laurels, culture of idleness, civil service culture of coming to work by 8 am and leaving by $4 \mathrm{pm}$, self-servicing culture whereby attention is focused on promotional issues rather than contributions to knowledge, learning and societal development. Nonetheless, there is need to approach the problem more systematically in order to identify critical actors and relationships that led to the gradual deintellectualization of the academia in the country.

Figure 1 presents a picture of the gradual deintellectualization of the academia that took place in Africa following the independence in the continent as from 1954. Each of the green balls in the figure represents the magnitude of intellectualism and by implication the value placed on the academia in African societies with the passing time. 


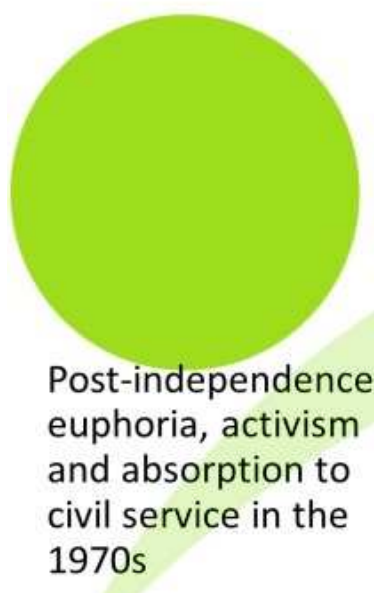

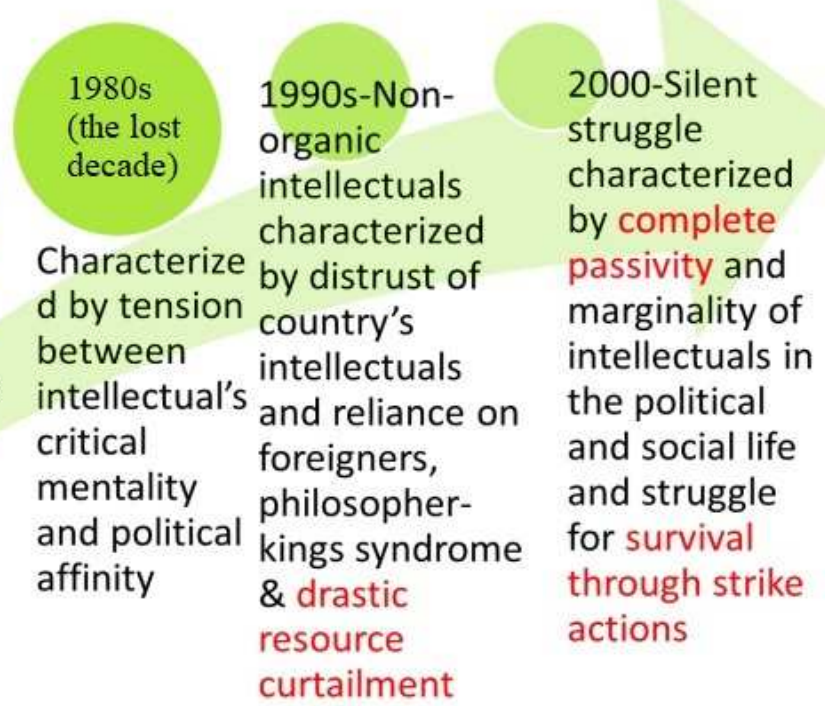

Figure 1. Political Environment and Deintellectualization in Africa.

Source: Extracted from Mkandawire (2005, p. 44).

Babalola (2015) argued that before and at independence, African societies depended so much on the intellectuals to actualize their dreams to dethrone the well-articulated Colonialists. The independence struggles were intellectual battles led by foreign-grown intellectuals such as Nyerere of Tanzania, Nkrumah of Ghana and Jomo Kenyatta of Kenya. Between 1960 and 1980, most African countries experienced post-independence euphoria, activism and absorption of the few educated people into the civil service. However, as politicians gained stability, especially in the 1970s and 1980s in most countries of Africa, there was a general tension between intellectual's critical mentality and political affinity. Some countries like Nigeria experienced incessant military rules with little or no tolerance for objectivity and critical mentality of the academia. For the intellectuals to gain access to political power, many of them compromised their critical stands and morality of the intellectual to seek the truth, speak the truth and stand for the truth for the general good of the society. At this juncture, the international dimension also came in in form of anti-intellectual policies pushed by the International Monetary Funds (IMF). Table 2 illustrates the gradual erosion of public support for the intellectual system in Africa. 
Table 2. Gradual Erosion of Public Support for Intellectual System in Nigeria

\begin{tabular}{|c|l|}
\hline $\begin{array}{c}\text { Surplus } \\
\text { (1948-1974) }\end{array}$ & $\begin{array}{l}\text { By 1973/1974, there were 6 universities with 25,900 students competing for } \\
\text { exiting resources. By this time, the University of Ibadan had a surplus of } \\
\text { N844, 901. No public scrutiny and no criticisms. }\end{array}$ \\
\hline $\begin{array}{c}\text { Slightly } \\
\text { diminishing } \\
(1975-1977)\end{array}$ & $\begin{array}{l}\text { By 1975, there were } 13 \text { universities with 32, 286 students to share the existing } \\
\text { resources. The number of competing public sectors increased from 14 } \\
(1970-1974) \text { to } 24 \text { in 1975-80. National income could not cope with demands. } \\
\text { Thus, University of Ibadan experienced a shortfall of 243.403 Nigerian Naira } \\
\text { in 1975 }\end{array}$ \\
\hline $\begin{array}{c}\text { Seriously } \\
\text { diminishing } \\
(1977-1979)\end{array}$ & $\begin{array}{l}\text { In 1979, there were 29 universities housing about 49,000 students. The share } \\
\text { of education in the total planned expenditure fell from 11.9\% to 7.2\%. } \\
\text { In1977/1978. UI requested for N53.4 million but got N25.8 million. Public } \\
\text { scrutiny/criticisms heightened with NUC empowered }\end{array}$ \\
\hline $\begin{array}{c}\text { Slightly } \\
\text { disturbing } \\
(1980-1986)\end{array}$ & $\begin{array}{l}\text { Disturbing-deficits in resources could no longer be covered by marginal ad- } \\
\text { justments. Public projects increased to 28. In anticipation of SAP, Nigeria } \\
\text { reviewed National Plan twice. This reduced education share from 7.2\% to } \\
\text { 3.6\% and brought education 1\% below 1960. Capital appropriation per univer- } \\
\text { sity dropped from N350 million (1982) to N41 million (1985). In University of } \\
\text { Ibadan, Medicine and pre-clinical facilities fell below the requirements of Ni- } \\
\text { gerian Medical Council. COREN threatened not to recognize graduates produ- } \\
\text { ced in 3 out 4 departments in Technology }\end{array}$ \\
\hline
\end{tabular}

Source: Babalola (2011).

In the words of Meredith (2006, pp. 368-369) by mid-1980s... African governments could no longer afford to maintain proper public services. Roads, railways, water, power and telephone systems deteriorated; schools, universities and hospitals were starved of funds; scientific facilities and statistical offices became early casualties... A drastic erosion of civil service salaries wrecked what was left of the morale, honesty and efficiency of civil servants... Between 1986 and 1990 alone, some 50,000 to 60,000... managers left Africa. Bereft of expertise, African civil services became renowned for pervasive absenteeism, endemic corruption and low morale; incapable of performing basic tasks... Wage-earners were pushed into the informal economy of petty trade and backyard businesses. Public resentment towards the state and its agencies grew... 


\section{LOW INVESTMENT IN ADVANCED HUMAN CAPITAL INCLUDING RESEARCH AND DEVELOPMENT}

Below are fundamental issues that have limits Africa's growth and development. Such include:

1. Research and Development (R\&D) is what scientific, technological and medical companies engage in to find new designs, software and products.

2. By its nature, $R \& D$ is both private and public good. Government's involvement is needed to provide prerequisites, incentive regime, intellectual property regime, licensing, and market policies.

3. About $85 \%$ of global R\&D expenditure is concentrated in high-income $\&$ highly competitive countries where most new knowledge is created.

4. No African country among the top 10 nations in $R \& D$ expenditure. Whereas, 8 of 10 countries with lowest R\&D expenditure were in Africa

The European Union (EU), set a goal to achieving R\&D expenditure of $3 \%$ of GDP by 2010 compared with 1\% of GDP set in the 1980 Lagos Plan of Action and reaffirmed by African leaders in 2007 (Onyenekenwa, 2011).

By 2006, Sweden (3.6), Korea (3.47), Japan (3.44) had already exceeded that goal. As far as 2002 , US spent \& 286 billion on R\&D when there was no R\&D spending in Angola (Nanyaro, 2004). Similarly, many of the countries in Africa actually devoted lower than 1\% of GDP to R\&D (Mutume, 2010, p. 1). Furthermore, in 38 years, the World Bank supported Nigeria to the tune of about $38 \%$ of the country's total education budget in each of the eight fiscal years. Lending for university education projects accounted for as much as $43.75 \%$ of Nigeria's total education budgets in 1990 and $17.74 \%$ in 2003 (Babalola, 2011). According to the World Bank (1994, p. 81 ) "Nigeria has been Africa's leading borrower for higher education" since 1986. There is a wide gap in scientific papers published when comparing and contrasting the Industrial countries with Africa.

\section{Industrial Countries:}

1. Publication rate doubled in the past three decades.

2. Scientific capacity is expanding rapidly in China, Hong Kong, Singapore, South Korea, and Taiwan.

3. Academic journals has been doubling roughly every five years.

4. New titles reflecting increasing narrow specialties.

5. Between 1981 and 1984, all countries that passed the ranking test of published scientific papers per capita were industrial economies. The rate has doubled in the past. 
6. Between 1986 and 1996, the number of applications increased by 42, 46 and $71 \%$ in Brazil, India and the United States respectively.

7. By 1996, industrial countries had about 20 times as many personal computers [224 versus 12 per 1,000 people].

8. By 1996, industrial countries had more than 100 times as many Internet hosts [203 versus approximately 2 per 10,000 people].

\section{African Countries:}

1. Published papers in sciences and social science increased from 4,337 in 1981 to 5,839 in 1995 .

2. Citations increased from 29,740 , in $1981-1985$ to 56,110 in $1993-1997$ (World Bank, 2000).

3. Since none of the African countries could described as truly industrialized then no country passed the ranking test of published scientific papers per capital (World Bank, 2000).

4. No data for Africa (World Bank, 2000).

5. In 2000, Sub-Saharan Africa recorded 10 personal computers per 1000 people compared with 53 in Europe and Central Asia (Babalola, 2010).

6. In 2001, the number of Internet users was 5, 300 in Sub-Saharan Africa against 18,778 in Europe and Central Asia (Babalola, 2010).

\section{FINANCIAL MANAGEMENT}

However, in spite of the tremendous expansion of HE in Africa, only $5 \%$ of the qualified population has been covered compared with $70 \%$ in the high income regions (HIR). Already, there is the challenge of how to finance quality access to HE Coupled with this, there is system inefficiency and wastages $170 \%$ of the per capita income is spent annually compared with $20 \%$ in the US. Moreover, universities in Africa experienced more dropouts in $50 \%$ of students than in high income regional. Sub-Saharan Africa lost $\$ 700$ million owing to brain drain to US in return for $\$ 600$ million received as education aids from USA with a net GATS loss of $100 \mathrm{~m}$ in the scholarly trade market. Public expenditure per student fell from $\$ 6300$ in 1980 to $\$ 1240$ in 1995 in Africa. Unfortunately, increasing integration of ICT will likely increase the cost of HE in Africa. This is because; the cost of Internet access per month which was $\$ 120$ in the US was $\$ 13,000$ in SSA. Furthermore, increased application of market mechanisms will force HE to make cost and financial reforms that would subject public funding to further diminution and competitive funding mechanisms. International Partners like the World Bank want evidence 
of accountability. To this end higher education needs more money and more innovation in funding, more responsible management of funds and cost efficiency.

\section{WAYS TO MAKE KNOWLEDGE \\ AND INNOVATION WORK BETTER IN AFRICA}

We can see from the forgoing that indigenous knowledge is important for development activities to be successful. Solutions offered by development project experts often at times failed because such solutions do not fit well with the local knowledge system. Indigenous knowledge is capable of providing alternative methods of viewing and solving developmental problems, since the success of development often depends on local participation. Familiarity with indigenous knowledge can therefore help experts to understand and communicate with local people thereby enhancing the possibilities for participatory approaches to development and sustainability of these efforts.

Nigeria's current development efforts cannot be all that successful without injecting some elements of indigenous education into the formal education system. Although we know that indigenous education main aims are character and vocational training, and preparation for adulthood. The approach was however holistic in that it encouraged the development of the spirit and the body by combining physical training with vocational training, and intellectual training with spiritual development. Prior to this this time the curriculum may be considered relevant to the need of the society more so as it prepared people for gainful employment. Today, however, the curriculum may be considered to be too restrictive and inadequate for technological changes currently taking place. That is why there is an urgent need for robust research into all aspects of indigenous education in order to identify other features that can be made relevant for our development efforts.

However, a caveat must be noted that the recognition of value of indigenous knowledge does not imply a wholesale rejection of modern technology and uncritical return to traditional technologies if better alternatives are available. The absence of viable alternatives that meet the following criterial: (1) technical and environmental soundness, (2) social desirability, (3) economical affordability and (4) sustainability has opened up the desire to search for, consider and incorporate indigenous knowledge into development activities (Philips, Titilola, 1995, p. 11).

In this paper we have also discussed indigenous knowledge and its role in international development. The lessons here is that we should be able to cooperate 
with the external world without losing much of our own identity. Suffice is to say that we must admit that not all modern technologies will be useful and readily applicable or adaptable. In this regards, indigenous knowledge will be of immense assistance in discerning useful practices for selection as efforts to develop appropriate technologies for most developing countries have been disappointing. The disappointment is due in part to the environment and socio-economic and educational peculiarities of the region which are either unrecognized or inadequately understood and appreciated.

\section{CONCLUSION}

The paper looks at Africa in the global economic history stressing the fact that Africa was playing a leading role during the Neolithic revolution during which crops such as coffee and kola nut were domesticated in Africa. During the industrial era, Africa left its place of honour owing to many reasons one of which is the inability of the continent to join the global post-Second World War search for knowledge and her failure in adapting her own indigenous knowledge to fit into the prevalent development activities. Based on this background, the paper highlights six hindrances to renaissance explosion in knowledge in Africa with special emphasis on inefficiency in indigenous knowledge systems following colonialism. It further highlighted major challenges such as low capacity to invest in advanced human capital; low scientific and analytical capacity; low level of access to education; low digital capacity; low public interest in knowledge systems and low strategic aspiration facing Africa in developing efficient indigenous knowledge systems. Finally, the paper suggests that Africa countries should transform their indigenous knowledge systems strategically for effective global competition in a knowledge economy by exposing development experts to African Indigenous knowledge system concepts and utility. The significance and importance of indigenous knowledge should be progressively emphasized so that the utility can be seriously looked into and probably adopted.

Critical and self-critical as we might be about the status of the African academy and intellectuals. the narrative would not only be incomplete, but altogether flawed if one did not applaud the resiliency as well as the resourcefulness they have demonstrated living under impossible conditions. Indeed, nothing short of utmost tribute should be paid to African intellectuals for having survived the last few decades of a dictatorial political environment that has been extremely hostile to highly contemptuous of committed intellectuals, 
especially those who have refused to compromised their academic integrity. Under many dictatorships, intellectuals have been among victims of the state terror, some being subjected to arrest, imprisonment, detention, exile, murder and even open execution. In this sense, African intellectuals, like their societies, deserves nothing short of praise for not just surviving conditions under which productivity is next to impossible, but for emerging with works that is internationally competitive. To survive a single day trying to be intellectually productive under today's African economic conditions is overwhelming challenge and tricky exercise in intricate negotiations around electric power outages, water shortages, traffic paralysis, space scarcity and perpetual scrabbling over chronically diminishing essential resources.

\section{REFERENCES}

Babalola J. B. (2010), Transition from Chalkboard to Digital Whiteboard: Keeping Pace with Challenges of 21st Century Learning Technologies in a Developing Economy, Journal of Educational Review, 3(2), pp. 161-172.

Babalola J. B. (2011), World Bank Support for Nigerian Higher Education: Pleasure, Pains and Pathway Towards a Knowledge Economy. Inaugural Lecture, Ibadan: University of Ibadan.

Babalola J. B. (2012), Role of Education and Research in Rethinking Post-Colonial African Development, [in:] A. O. Ayeni, U. G. Emetarom, A. O. Okwori, J. A. Undie, J. E. Okon (Eds.), Managing Education for National Transformation, Ibadan: NAEAP Publications, pp. 437-458.

Babalola J. B. (2013), Education for Sustainable Development in Africa, [in:] S. Oni (Ed.), Challenges and Prospects in African Education Systems, Trafford Publishing, pp. 875-912.

Babalola J. B. (2014), Reintellectualization of the Deintellectualized Academia in Africa: Process, Product and Pathway, [in:] A. O. U. Onuka (Ed.), Analyzing Educational Issues in Honour of Emeritus Professor Pai Obanya, Ibadan: Society for the Promotion of Academic and Research Output, pp. 344-356.

Babalola J. B. (2015), Tossed by Global Revolutionary Winds: Lessons from Post-Independence Education Reforms in Africa, [in:] K. M. B. Islam, S. N. Iftektar (Eds), International Perspectives Contemporary Education Policy, London, New Delhi, New York, Sydney: Bloomsbury and IIM, Kashipur, pp. 17-32.

Babalola J. B., Emunemu B. O. (Eds.) (2003, 2006), Issues in Higher Education: Research Evidence from the Sub-Saharan Africa, Lagos: Bolabay Publications.

Babalola J. B., Popoola L., Onuka A., Oni S. Olatokun W., Agbolahor R. (2008a), Reforming Higher Education in Africa, Ibadan: HERPNET and University of Ibadan Postgraduate School.

Babalola J. B., Popoola L., Onuka A., Oni S., Olatokun W., Agbolahor, R. (2008b), Revitalization of African Higher Education, Ibadan: HERPNET and University of Ibadan Postgraduate School.

Babalola J. B., Popoola L., Onuka A., Oni S., Olatokun W., Agbolahor, R. (2008c), Towards Quality in African Higher Education, Ibadan: HERPNET and University of Ibadan Postgraduate School.

Bamiro O. A. (2012), The Nigerian University System and the Challenges of Relevance: Convocation Lecture University of Lagos, Akoka-Lagos, 12 January. 
Beck U. (1992), Risk Society: Towards a New Modernity, London: Sage.

Dewey J. (1938), Experience and Education, New York: Macmillan.

Held D., McGrew A., Goldblatt D., Perraton J. (1999), Global Transformations: Politics, Economics and Culture, Stanford, CA: Stanford University Press.

Kotschi J. A., Waters-Bayer A., Adelhelon R., Hoeste U. (1989), Eco Farming. Tropical Agroecology, Weikersheim: Magraf Verlag.

Mazrui A. A. (2005), Pan-Africanism and the Intellectuals: Rise, Decline and Revival, [in:] T. Mkandawire (Ed.), African Intellectuals: Rethinking Politics, Language, Gender and Development, Dakar: CODESRIA, pp. 19-46.

McNeill J. R., McNeill, W. H. (2006), Verkottunut ihmiskunta. Yleiskatsaus maailmanhistoriaan, transl. N. Vilokkinen, Tampere: Vastapaino.

Meredith M. (2006), The State of Africa: A History of Fifty Years of Independence, London: Free Press.

Migo M. G. (2004), The Role of African Intellectuals and "the Way Dorward" for the Social Sciences, [in:] R. Mukana, M. Rutanga (Eds.), Confronting Twenty First Century Challenges: Analyses and Re-dedications by National and International Scholars, Vol. 1, Kampala, Uganda: Faculty of Social Sciences, Makerere University, pp. 27-40.

Mkandawire T. (2005), African Intellectuals and Nationalism, [in:] T. Mkandawire (Ed.), African Intellectuals: Rethinking Politics, Language, Gender and Development. Africa in the new millennium, London, UK: Zed Books, CODESRIA Books, pp. 10-55.

Mutume G. (2010), Rough Road to Sustainable Development, Africa Renewal, 18(2), pp. 19-20.

Nanyaro G. F. (2004), Support to Legislative Development in Tanzania and Preparation of Adraft Aquaculture Policy, Kenya: Kenya project.

Nwokeabia H.; United Nations. Economic Commission for Africa (2001), Why industrial revolution missed Africa: a "Traditional Knowledge" Perspective, Addis Ababa: (C) UN. ECA, https://hdl.handle.net/10855/457

Onyenekenwa C. E. (2011), Nigeria's Vision 20:2020 - Issues, Challenges and Implications for Development Management, Asian Journal of Rural Development, Vol. 1, pp. 21 V40.

Richard P., Slikkerveer L. J., Philips A. O. (1989), Indigenous Knowledge Systems for Agriculture and Rural Development: The Cikard Inaugural Lectures (Studies in Technology and Social Change, No. 13), Ames, Iowa: Technology and Social Change Program, Iowa State University and Academy for Educational Development.

Philips A., Titilola T. (1995), Indigenous Knowledge Systems and Practices: Case Study from Nigeria, Ibadan, Nigeria: Nigerian Institute of Social and Economic Research (NISER).

Soubbotina T. P. (2004), Beyond Economic Growth: An Introduction to Sustainable Development, Second Edition, Washington, D.C.: (C) World Bank, https://openknowledge.worldbank. org/handle/10986/14865 License: CC BY 3.0 IGO.

Sousa E. C., Raizada M. N. (2020), Contributions of African Crops to American Culture and Beyond: The Slave Trade and Other Journeys of Resilient Peoples and Crops, Frontiers in Sustainable Food Systems, December 15, 2020, https://doi.org/10.3389/fsufs.2020.586340

Stehr N. (1994), Knowledge Societies, London, EK: Sage Publications.

Wallace S. (2007), Oxford Dictionary of Education, Oxford, UK: Oxford University Press.

Warren D. M., Cashman K. (1989), Indigenous Knowledge for Agriculture and Rural Development: Some Practical Applications (Paper presented at the conference on Indigenous knowledge systems), Washington, D.C.: ABD.

World Bank (1994), World Development Report 1994: Infrastructure for Development, New York: 
Oxford University Press. (C) World Bank, https://openknowledge.worldbank.org/handle/ 10986/5977 License: CC BY 3.0 IGO.

World Bank (2000), The World Bank Annual Report 2000, Vol. 1: Annual Review and Summary Financial Information, Washington, D.C. () World Bank, https://openknowledge.worldbank. org/handle/10986/13935 License: CC BY 3.0 IGO.

World Bank (2007), Recruiting, Retraining, and Retaining Secondary School Teachers and Principals in Sub-Saharan Africa, Washington, D.C.: World Bank.

\section{TRANSFORMING INDIGENOUS KNOWLEDGE AND INNOVATION SYSTEMS FOR AFRICAN INTELLECTUAL DECOLONIZATION AND RENAISSANCE}

\section{Summary}

The application of knowledge (measured in term of entrepreneurship and innovations, research and development, and software and product design) has become one of the spring boards of economic growth. The paper highlights six hindrances to renaissance explosion in knowledge in Africa with special emphasis on inefficiency in indigenous knowledge systems following colonialism. It further highlighted major challenges such as low capacity to invest in advanced human capital, low scientific and analytical capacity, low level of access to education, low digital capacity, low public interest in knowledge systems and low strategic aspiration facing Africa in developing efficient indigenous knowledge systems. The authors, drawing on existing literature and expert consultations, clearly identified and established major challenges being faced by African countries in leveraging on intellectual advances and suggest ways to transform the knowledge and innovation system in moving the continent towards the knowledge economy.

Keywords: indigenous knowledge; innovation systems; intellectual decolonization; renaissance.

\section{PRZEKSZTAŁCANIE RDZENNYCH SYSTEMÓW WIEDZY I INNOWACJI NA RZECZ INTELEKTUALNEJ DEKOLONIZACJI I ODNOWY AFRYKI}

Streszczenie

Wykorzystanie wiedzy (mierzonej w kategoriach przedsiębiorczości i innowacji, badań i rozwoju oraz projektowania oprogramowania i produktów) stało się jednym z pierwszych impulsów wzrostu gospodarczego. W artykule uwypuklono sześć przeszkód dla gwałtownego renesansu wiedzy w Afryce, ze szczególnym naciskiem na nieefektywność rdzennych systemów wiedzy zaistniałych po okresie kolonializmu. Ponadto zwrócono uwagę na główne wyzwania, takie jak niska zdolność inwestowania w zaawansowany kapitał ludzki, niskie możliwości naukowe i analityczne, niski poziom dostępu do edukacji, niskie kompetencje cyfrowe, słabe publiczne zainteresowanie systemami wiedzy i niskie aspiracje strategiczne, przed którymi stoi Afryka w rozwijaniu efektywnych lokalnych systemów wiedzy. Autorzy, bazując na dostępnej literaturze i konsultacjach eksperckich, jasno zidentyfikowali i określili główne wyzwania stojące przed krajami afrykańskimi w zakresie wykorzystania postępu intelektualnego oraz zaproponowali sposoby przekształcenia systemu wiedzy i innowacji w kierunku podążania kontynentu ku gospodarce opartej na wiedzy.

Słowa kluczowe: rdzenna wiedza; systemy innowacji; dekolonizacja intelektualna; odnowa. 